\title{
The Way of Salvation in Gary Snyder's Poetry
}

\author{
Liu Zhijie \\ Beihang University Beijing 100191
}

Keywords: Gary Snyder; poetry; salvation.

\begin{abstract}
The American poet Gary Snyder's poetry embodies rich Zen thoughts and ecological thoughts. He conveys the mutual dependence and reciprocal protection between human beings and nature in the course of the development of modern society. His poetry is based on an idealistic poetic realm of Chinese Zen thoughts and Thoreau. The ideal existence practice of Thoreau humanism and the Native American literary ecological thought are the main concepts in his poetry. Snyder integrates the quintessence of Zen ideology and the method of eco-poetic salvation in poetic creation. He hopes to find a new spiritual sustenance for the soul, return purely to "the heart", "enlighten" in the secular world, and eventually achieve the "bright heart".
\end{abstract}

Gary Snyder, an environmentalist and great American poet, won the Pulitzer Prize for poetry in 1975 for his poetry collection “Turtle Island”. As a Zen believer, under the influence of "Dependent Origination and the Emptiness of Nature”, Snyder integrates Zen thoughts that are the very Zen aesthetics in his poetry. He comprehended the taste of life philosophy in his daily life, experienced various dwelling forms of life in practice, purifies the soul, and expressed the inner feelings through his works. His works are concerning the return to nature, advocating the way of natural harmony and Buddhist compassion. Taoist and Confucian thought in Snyder's poetry are manifested as a unity of the heaven and the earth, demonstrating his awareness of ecological salvation.

\section{The Theme of Snyder's Zen Poetry}

Gary Snyder's poetic expression is based on Zen thoughts and integrates the main value of Chinese Taoists and Confucians. The poems embody view of nature and environment, the image tendency and the ecological thought.

\subsection{Snyder's “Nature View” of Confucian Humanistic Thought}

"Benevolence is the characteristic element of humanity". The theory of post-modernism literary creation starts with individual will, emphasizes personal experiences and universal experience, and gives priority to the subjective speculation of the presence and departure of personal emotions. Criticism at the level of symbolic significance of work excludes metaphysical mysticism, highlights the self, and highlights the judgment of material character and traditional value system. "Gary Snyder's artistic tendency is generally American native culture, but it is influenced by the Chinese traditional culture introduced into the United States. The concept of Confucianism in the work presents the 'benevolence' that concerns for the ecological environment." Gary Snyder accepts Confucian thoughts translated by Thoreau and Emerson, explores the theory of Confucius and Mencius, and incorporates the attributes of personal responsibility and freedom and social relations in the work. The poetry presents the mutual relationship between the natural environment and the human environment. He believes that the contradiction between social value and individual value lies in self-practice and the realization of self-value. Based on the equality and openness in all beings in Buddhism and the "benevolence and love" in Confucianism, Snyder combined the American aboriginal postmodern culture to highlight the self-worth, "benevolence" and the return to nature. Gary Snyder used poetry to undertake political and social debates and hoped that he could use “Xing Guan Qun Yuan” as a way to get from literature and from politics. 


\subsection{Taoist Aesthetic Features in Snyder's Poetry}

Gary Snyder had practiced in Rinzai, a Japanese temple belonging to Zen. At the same time, Gary Snyder was enthusing about Lao Tzu's “The Tao Te Ching” and had a deep American-style experience of Laozi and Zhuangzi culture, advocating the appreciation of nature and "do nothing and do everything". The innate American wilderness cultural complex was intertwined with Laozi's "Tao" and permeated into the Confucian temperament of Buddhism. Therefore, his typical western speculation creates a new ecological humanistic thought that integrates Eastern and Western cultures. Gary Snyder appeals to ecological and environmental awareness through poetic creation. From the nature of substances he strives for the compatibility of all things and extracts everything from nothing to serve everything. Therefore, in the pursuit of nature and humane spirit, his poetry was rooted in ecology and spiritually suited to the natural way of Taoism in Laozi and Zhuangzi. "As a poet, it is nature that speaks to me in its own voice," he said, "Nature is what the ancient poets called the Great Goddess and the Master, the Muse of westerners. I regard this voice as a perfectly real entity.” It can be seen from this that he purified the essence of words in his daily life, praised the natural ecology in the poetry and emphasized the lyrical context of artistic conception, and therefore formed the narrative style of poetry, and the aesthetic style of reconstruction of post-deconstruction lyric system.

\subsection{Snyder's Aesthetic View of Ecological Poetics}

Gary Snyder's ecological poetics advocates listening to the sound of nature that founded on the awe of nature. He emphasizes the harmony between the natural rhythm of the poetry and the rhythm of the natural atmosphere, approaches the essence of life and the soil, explores the modern context generated by the meta-language, ignores the blindness the materialism imposed to thought creation in the post-industrial era, and maintains the freshness of the word in context instead of what artificially defined words refer to. Gary Snyder tries to make poetry more colloquial and use narrative to trace the original musicality of the language. He attaches great importance to the strong primitive vitality of the spoken language and the tradition of cultural information. The interpretation of the relationship between spoken language and ecology at the philosophical level is a lively expression of the diversity of life and the complexity of natural vitality. Gary Snyder's aesthetics of ecological poetics is linked to his traditional Western education and blends with the Chinese Zen culture, the Confucianism and Taoism culture, which are "not to care one way or another" and "do nothing and do everything". He tries to use the "yuan" to present the earth's original features and cultural roots as well as the truth of matter: "A humpbacked whale / jumping out of the water to breathe / swallowing the herring / nature is not a book, but a performance.”

\section{The Main Cause and Salvation Manifestation of the Salvation Consciousness in Snyder's Poetry}

\subsection{The Main Cause of Salvation Consciousness in Snyder's Poetry}

The modern society's advocacy of irrationalism makes human beings fall into the predicament of the absence of value and spiritual wasteland. The rational pursuit of Gary's poetry to return to the natural ecology and the search for the source of the soul's happiness and safe haven in nature are the main course of his poetic redemption consciousness. Human and nature should have been harmonious entities of meaning. Because of the invasion of modern productive economy, the destruction of civilization and war, the loss of beliefs and the loss of conscience, the transformation of the value system into the nature in the poetic structure standing in the opposite of human beings, and conflicts occur between human nature and morality. The state of chaos, loneliness and emptiness circulate back and forth. The uncertainty between the realization of the fixed fulcrum and the constructive basis of meaning contrasts the existence of natural stability. Man's dependence on nature is the existence of the survival value space. When the Zen elements and ecological poetics infiltrate each other, the cognitive style directly or indirectly expresses the relationship between nature and human in the poetry creation, thus further explaining the new way to appreciate the 
nature of the poetry, realizing self-redemption and the meaning of life. This forms a specific image of Gary's poetry creation, enriches the symbolism in his poetry and the strict structure of salvation, and reflects the ecological humanism.

\subsection{The Embodiment of Salvation Awareness in Snyder's Poetry}

Under the background of Zen thoughts and ecological poetics, Gary Snyder's binary opposition to the salvation consciousness is embodied, constructing an ideal space that transcends civilization and wilderness. In "Piute Creek" the poet chose the wilderness as the setting. In the first section, it creates a wilderness world of peaceful and harmonious atmosphere with reference to natural images such as mountains, trees, creeks, moons, and rocks. In the second section, the products of the civilized world in the process of the development of the times come into our sight, "the scraps that come along with people" and the "words and books", "fallen" or "disappearance" narratives the gap between the poet's living space and human civilization, means that the organic imagery of the "I" and the natural wilderness live together in the wilderness homeland. The "I" is the subject of "gazing", the entity that is being stared at by the nature. The poet conducts the ideal of achieving equality between nature and human beings to accomplish the springing from Anthropocentrism to Eco-centrism, and conveys the ecological ethical concept of "reverence for life". At the same time, the use of natural scenes and changes in values all together reflect the creative application of Zen ideology.

In the details of life, Snyder seeks the metaphysical philosophy of life and integrates the Chinese context. His poetry embodies the profound implication and poetic conception of classical Chinese poetry; poetry and painting, poetry and thought, poetry and understanding makes his poetry the combination of sensual beauty and the sober speculation of Chinese and Western culture, and this is really original and unique in United States during the 1970s. It is the realm of Zen Buddhism practice to see through the perspective of the wild world of poetry, the inherent order of nature and the harmonious coexistence of mankind, the harmonious coexistence of life and the inanimate things, and in the state of subject equality, the words have endless meanings. The cultural connotation and cultural significance of Gary Snyder's poetry is the result of the development of human civilization. The artistic features and manifestations of the perfect combination of Zen implication and poetry creation reflects the living state of Gary Snyder's redemption consciousness, and the poet's pursuit of the unique life style and the desire for the dual freedom of the body and spirit. Only by clearly understanding the interdependent relationship between man and nature will it be possible to "travel" in the space where all things in the universe are blended and obtain the "clearness and concentration" of the soul. Only then can one truly see the value of the nature of things.

\section{Conclusion}

Gary Snyder respects the beauty of harmony in nature, attaches great importance to the freedom in life consciousness, he hopes to live in a natural world with evergreen nature and a spiritual world without the sound of killing, but the ideals are shattered by reality. From the combination of artistic experience and Zen thoughts, Gary Snyder practiced the ecological ideal of social moral criticism in poetic creation. Through the exploration and analysis of Gary Snyder's poetry, we must reflect on the salvation of nature and human beings: when human greed brings disaster to human beings and nature, the existence of life is meaningless.

\section{References}

[1] Qiu Shicun. The Zen Consciousness in Gary Snyder's Poetry [J]. Journal of Yangtze Normal University, 2017, 33(02):90-97+143.

[2] Qiao Liping, Liu Sijia. An analysis on the Translation of Han Shan Poetry by Gary snyder, a Tang Dynasty Monk from his Hometown to Far Away [J]. Heilongjiang Social Sciences, 2017(02):120-123. 
[3] Luo Jian. Gary Snyder’s “Deep Ecological Culture” and its Literary Significance [J]. Research of Chinese Literature, 2016(03):14-17+48. 